\title{
Contents, Vol. 191, 1985
}

No. 1 Original Paper $\cdot$ Travaux originaux $\cdot$ Originalarbeiten

Treatment of Endophthalmitis With and Without Pars plana Vitrectomy

Verbraeken, H.; van Laethem, $\mathrm{J} \quad 1$

Epidemiology of Acute Angle-Closure Glaucoma: Incidence and Seasonal Variations

David, R.; Tessler, Z.; Yassur, Y 4

Anomalie oculaire inhabituelle de la trisomie 9p: dépigmentation rétinienne

Bursztyn, J.; Dufier, J.L.; Granier, G.; Vinurel, M.C.; Rethore, M.O.; Badoual, J. . . 8

Connective Tissue Changes Associated with Inferior Epiblepharon, Epicanthus, and Keratoconus

Daxecker, F.; Mikuz, G 12

Malignant Teratoid Medulloepithelioma in an Adult

Litricin, O.; Latkovic, Z 17

Some Ultrastructural Aspects of the Vitreoretinal Juncture

Malecaze, F.; Caratero, C; Caratero, A.; Arne, J.L.; Mathis, A.; Bee, P.; Planel, H. . 22

Intraokulare Penetration systemisch applizierter Cephalosporine unter Steady-state-Bedingungen im Tierversuch

Völker, B.; Mester, U.; Mendel, N 29

Pupil Increment Thresholds Are Influenced by Color Opponent Mechanisms

Krastel, H.; Alexandridis, E.; Gertz, J

35

Oscillatory Potentials of the Electroretinogram in Patients with Unilateral Optic Atrophy

Wachtmeister, L.; el Azazi, M

Veränderungen der retinalen Hämodynamik im Alter

Richard, G 51

Clinicopathologic Case Report · Description clinico-pathologique de cas $\cdot$ Klinischpathologische Fallbeschreibung

Retinal Vascular Tortuosity and Recurrent Retinal Haemorrhages in a Patient with Non-

Chromaffin ParagangliomaGrønvold Olsen, E.; Ringvold, A.; Refsum, S.B

Book Reviews $\cdot$ Livres nouveaux $\cdot$ Buchbesprechungen

61

Announcement - Communication - Ankündigung 64

No. 2 Original Paper Travaux originaux Originalarbeiten

Circular Subtotal Retinectomy and Inferior Semicircular Retinotomy: Preliminary Report

Haut, J.; Seigle, P.; Larricart, P.; Flamand, M.; Vachet, J.M 65

Trabeculoperforation? Trabeculoretraction? Trabeculoplasty? Review of the Various

Designations Used for Laser Treatment in Primary Open-Angle GlaucomaMoulin, F.; Haut, J.;

Abboud, E 75

Laser and Glaucoma: Our Experience

Reibaldi, A.; Uva, M.G.; Scuderi, G.L

Intraocular Lens Power Calculations: The Optimal Approach

Boerrigter, R.M.M.; Thijssen, J.M.; Verbeek, A.M 89 
Rapid Diagnosis of Hepetic Infections by Immunoperoxidase Method (With 1 colorplate)Herbort, C.P.; Perentes, E.; Matter, M.; Faggioni, R.; Pyndiah, N

Index III

Uveitis with Allergy to Candidin

Bloch-Michel, E.; Timsit, J.C 102

Dégénérescence givrée (snail-track, snowflake degeneration) de la périphérie rétinienne:

Etude ultrastructurale

Bee, P.; Malecaze, F.; Arne, J.L.; Mathis, A 107

Combined Arterial and Venous Retinal Occlusion as a Presenting Sign of Systemic Lupus erythematosus

Kremer, I.; Gilad, E.; Cohen, S.; Ben Sira, 1114

Amaurosis Following Blood Loss

Caballero Presencia, A.; Martinez Hernandez, A.; Diaz Guía, E 119

Die Aufnahme von Kaliumjodid und seine Wirkung als Antioxidans in isolierten Kaninchenaugen

Elstner, E.F.; Adamczyk, R.; Kroner, R.; Furch, A 122

Clinieopathologic Case Report a Description clinico-pathologique de cas · Klinischpathologische Fallbeschreibung

Mesectodermal Leiomyoma of the Ciliary Body Extending into the Anterior Chamber

Orsoni, J.G.; Daicker, B.; Cardillo Piccolino, F 127

Book Reviews · Livres nouveaux - Buchbesprechungen 130

No. 3 Original Paper Travaux originaux Originalarbeiten

Augensymptome bei konnatalem Lymphödem

Gornig, H.; Mücke, J 133

Evaluation of Argon Laser Photocoagulation of the Posterior Pole in Oedematous Diabetic

Retinopathy

Segal, A.; Ducasse, A 139

A Case of Sex-Linked Juvenile Retinoschisis with Peripheral Vascular Anomalies

Keunen, J.E.E.; Hoppenbrouwers, R.W.J.N 146

Some of the Most Important Properties of Silicone Oil to Explain Its Action

Haut, J.; Larricart, J.P.; Van Effenterre, G.; Pinon-Pignero, F1 150

Bilan de 524 examens de Doppler cervico-encéphalique en pathologie oculaire

Warter, G 154

Differentiation of Retinal Circulation Times by Videoangiography

Richard, G.W 161

Biochemical and Immunological Response of Tears of 30 Aphakic Eyes Half of Which Had

Received Implants and the Other Half Contact Lenses

Lundh, R.L 164

Electron-Microscopic Study of Iris Nerves and Muscles in Diabetes

Ishikawa, S.; Bensaoula, T.; Uga, S.; Mukuno, K 172

Factor VIII Expression in the Human Embryonic Eye. Differences between Endothelial Cells

of Different Origin

Hyldahl, L 184

Kinetik der Aufnahme von Pherajod in das Kaninchenauge

Elstner, E.F.; Adamczyk, R.; Kroner, R.; Furch, A 188

Book Reviews · Livres nouveaux — Buchbesprechungen 
Announcement $\mathbf{\square}$ Communication · Ankündigung 196

IV

Index

No. 4 Original Paper · Travaux originaux — Originalarbeiten

Inherited Corneal Snowflake Dystrophy with Oculocutaneous Pigmentation Disturbances

and Other Symptoms (with 1 color plate)

Meretoja, J 197

New Ocular Findings in Gaucher's Disease: A Report of Two Brothers

Sasaki, T.; Tsukahara, S 206

Retinal Function in Mucolipidosis IV

Abraham, F.A.; Brand, N.; Blumenthal, M.; Merin, S 210

Vision Loss without Amsler Grid Abnormalities in Macular Subretinal Neovascularization

Roy, M.S 215

Combined Treatment of Herpetic Dendritic Keratitis with Blunt Spatula Debridement and

Trifluorothymidine (with 1 color plate)

Herbort, C.P.; Matter, M 218

Blue-Yellow Colour Vision Changes as Early Symptoms of Ethambutol Oculotoxicity

Polak, B.C.P.; Leys, M.; van Lith, G.H.M 223

Ocular Rotation as a Tool for Superior Oblique Tendon Exposure

Feretis, D.; Michalopoulos, E.; Gekas, L.; Scurtis, P 227

Zum Einfluss ausgewählter Arzneimittel auf Parameter der Konjunktival-Photoplethysmographie

Böhme, H.-R.; Schüler, H.; Brüggemann, S.; Walther, H 230

Untersuchungen mit dem computergesteuerten Perimeter Peritest iiber die Wirkung des

Cosaldons A + E auf glaukomatöse Gesichtsfelddefekte

Stark, $\mathrm{H} \quad 238$

Clinicopathologic Case Report Description clinico-pathologique de cas Klinisch-pathologische

Fallbeschreibung

Telangiectatic Hamartoma of the Iris and Ciliary Body

García-Alix, C; Quintana, M.; Satorre, J.; Cardesa, A 250

Book Reviews · Livres nouveaux — Buchbesprechungen 254

Author Index 258

Subject Index 259

S. Karger - Medical and Scientific Publishers

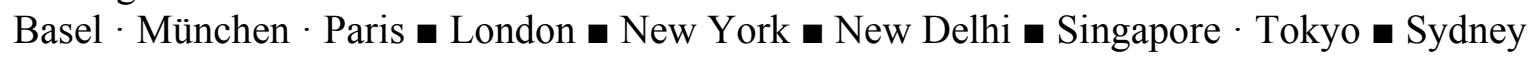

Drug Dosage All rights reserved.

The authors and the publisher have exerted every effort to No part of this publication may be translated into otherensure that drug selection and dosage set forth in this text languages, reproduced or utilized in any form or by anyare in accord with current recommendations and practice means, electronic or mechanical, including photocopy-at the time of publication. However, in view of ongoing ing, recording, microcopying, or by any information stor-research, changes in government regulations, and the age and retrieval system, without permission in writingconstant flow of information relating to drug therapy and from the publisher or, in the case of photocopying, directdrug reactions, the reader is urged to check the package payment of a specified fee to the Copyright Clearanceinsert for each drug for any change in indications and dos- Center (see 'Information for Readers and Subscribers'), age and 
for added warnings and precautions. This is particularly important when the recommended agent is a Copyright 1985 by

n. new and/or infrequently employed drug. S. Karger AG

P.O. Box

CH-4009 Basel (Switzerland)

Printed in Switzerland by Buchdruckerei Friedrich Reinhardt AG

Basel 